\title{
Dimensions of Teacher Performance Evaluation by Students in Higher Education
}

\section{OPEN ACCESS}

Manuscript ID:

EDU-2021-09023673

Volume: 9

Issue: 2

Month: March

Year: 2021

P-ISSN: 2320-2653

E-ISSN: 2582-1334

Received: 20.12.2021

Accepted: 30.01 .2021

Published: 01.03.2021

Citation:

(Fardin), Mohammad

Mohammadi. "Dimensions

of Teacher Performance

Evaluation by Students in

Higher Education." Shanlax International Journal of

Education, vol. 9, no. 2, 2021, pp. 18-25.

DOI:

https://doi.org/10.34293/

education.v9i2.3673

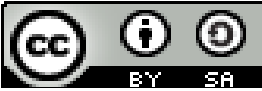

This work is licensed under a Creative Commons

Attribution-ShareAlike 4.0

International License

\author{
Mohammad Mohammadi \\ Lecturer, Herat University, Herat, Afghanistan \\ https://orcid.org/0000-0002-3056-4726
}

\begin{abstract}
Evaluation is one of the important aspects of the process of educational activities. And by it, the shortcomings and strengths of educational programs are realized. In the meantime, the evaluation of the professor as an important strategy to improve the quality of education has been considered by universities. Therefore, higher education centers set criteria for determining the competence of their teacher and thereby evaluate their performance through a codified process. The purpose of this type of evaluation is to improve the teaching method and to improve its effectiveness. In this library research, by combining topics and presenting the views of scientists and writers, we will be aware of the strengths and weaknesses, and in the end, some suggestions will be provided.

Keywords: Performance evaluation, Defenders, Opponents, Educational activities, Students, Teachers' morale
\end{abstract}

\section{Introduction}

Performance evaluation is a fundamental and important process for all organizations, especially for the higher education system. And its goal is to achieve excellence and improve quality in teaching-learning processes. Due to the needs and requirements that have been created today to ensure quality in the field of education and the higher education system, the need to reform and develop academic quality assurance systems is felt more than ever. On the other hand, the evaluation of the performance of teacher and faculty members in higher education systems has always been discussed and debated by those involved and the factors involved in the monitoring and evaluation systems. The set of effective factors in this system, from the departments of human resources development of universities to the educational departments and the office of supervision and evaluation in some universities, has paid attention to evaluating the performance of teachers at the end of semesters. And from a research perspective, various researchers have studied and diagnosed this complication.

All experts believe that if the implementation of the correct education system is successful, it will overcome many problems and difficulties and lead society to progress and development. Implementing a proper education system requires careful scientific and executive planning. Undoubtedly, one of the measures taken by officials to find out how well the goals of their program are achieved is the evaluation of human resources. Evaluation is a tool that can be used to achieve the goals of higher education. And it can be used to take fundamental steps towards advancing the goals of the education system. 
Saif defines evaluation and systematic examination of a subject to improve and make the program more effective by using the right methods. Saif considers teacher evaluation to be "determining the success rate of teachers and achieving their educational goals." Fattahi et al. Stated that; Sensitivity of education and attention to educational processes in universities, the need for evaluation that will improve the quality of education and ultimately improve the efficiency of the country's educational system

\section{Defenders of Student Performance Evaluation of Teacher}

Students' evaluation of teachers has been given a lot of attention due to its accuracy and potential applications. Accuracy and correctness of students' evaluation mean that students reflect the efficiency and effectiveness of teaching. Numerous studies by Marsh, Seldin, Murray and Moore Cole have shown that evaluation is a valid, reliable, simple, appropriate and valuable tool for some aspects of teaching. However, the effectiveness of this method depends on many factors, including the appropriateness of the tools used and providing a fair report of students on teaching. For example, Marsh claimed that student evaluation was the only effective teaching measure whose validity was fully established. Aleamoni stated that students' evaluation of teaching could also be credible and reliable. Also, like teaching reinforcement tools, the curriculum is useful and documents educational effectiveness. Baird states that evaluations show what is pervasive.

Based on many types of research in the field of evaluation by students, it has been concluded that; This method has features such as validity and stability and will be useful when comparing students' learning with other indicators. Nelson believes that the evaluation of teacher by students is widely used in higher education as the only reliable source of information on education.

\section{Proponents of Performance Evaluation Emphasize the following \\ - It allows students to express their opinions about their teacher, which creates political benefits for the institution.}

- Students are, by their very nature, the most extensive observers of teaching, and in turn, are in a unique position to evaluate the quality of the course and the commitment and preparation of the faculty.

- The reliability of students' observations is usually high. This, among other factors, depends on the number of respondents, so reliability can be ensured if appropriate samples are selected.

Student evaluation of the teacher is one of the best systems for evaluating the teacher's performance because students are the only ones who can evaluate whether the teachers have helped them in learning or not! Despite this view, it is argued that questionnaires cannot be the only source of information for teacher evaluation.

\section{Opponents of Evaluating the Performance of Teacher by Students}

There are also people who question and oppose the evaluation of teachers' performance by students. Research by psychologists in recent decades has clearly shown that personality traits and general environmental characteristics affect people's perceptions and judgments. There is no reason to expect students to be immune to this type of error in their evaluation of the teacher. On the other hand, students are not mature enough to judge education and are not familiar with the concept of teaching and learning. And they are simply deceived by an attractive show or good scoring. A fundamental question about questionnaires and scales is: Do they measure teacher performance? Serrano and Arámburo (2013) confirm that the scores set by students by university teachers refer to one of the products of educational activity: student satisfaction with teaching.

Many researchers criticize the fact that it is often not recognized that scales and questionnaires only measure feedback. And it is not possible to evaluate the educational activity or the performance of the teacher through them. Thus, the easiest way to evaluate a teacher's performance is to use questionnaires because they are easy to use, easy to process through computer programs, and displayed graphically to compare with others' grades. Also, managers can easily review numerical data. Eiszler 
(2000) states a significant relationship between the student's expected score and evaluation of teacher education. The higher the student score, the more positive the student evaluation. This has led to a rise in grades in higher education institutions.

According to Stroebe (2016), there is empirical evidence to suggest that tasteful teachers, those who give their students a good grade in return for a job, in turn, get a good grade from them. Conversely, teachers whose grades require the student to work harder receive worse grades. Therefore, there are serious doubts about the validity of students' evaluations of their teachers as a measure of the quality of education.

\section{Opponents of Teacher Performance Evaluation Emphasize the following}

- Some teachers believe that such assessments will impede their freedom of action in teaching and learning. And it will somehow put them in a lower position than the students. And it will reduce the motivation and lack of seriousness of teacher will lead to a drop in students' education and ultimately a decline in the quality of education at the university level.

- No progress has been made in differentiating teaching methods or the different fields of study in the questionnaires. These tangible differences do not exist in evaluation tools.

- The danger with questionnaires is that they can lead teachers to adopt short-term strategies that are detrimental to the learning process.

- Teacher evaluation by students is based in part on a learning theory. Therefore, outcome-based feedback is limited to the teacher because they do not deeply explore the aspects needed to guide him or her.

- The main problem with questionnaires is that they are used as the only source of teacher performance evaluation data.

\section{Effect of Evaluation on Educational Activities}

Student evaluation of teachers is a universal way to gather information about how teachers teach. The question is;
Are the students' education enough or not?

Do they learn anything from the training they receive?

Does student evaluation process of the training lead to improved teaching?

\section{Evaluation in three ways can improve teaching:}

1. When the evaluation system is new to the teacher and he wants to respond quickly to criticism.

2. When the teacher wants to improve his teaching.

3. When the teacher knows how to improve his teaching.

Wilson 1998 believes that educators work to improve weaknesses. Another group of researchers consider this evaluation due to the colonial and direct relationship between the student and the professor as necessary and the student's right and consider it the only tangible source and the best type of evaluation. In this regard, there is no difference between successful and poor students in terms of education. Betoret and Tomas (2003) point out that students are in a better position than their colleagues and the management of the college or university to judge the quality of education they receive. The US Academy of Arts and Sciences also believes that students' beliefs in determining and rewarding teachers are decisive and important. Zelby (1974) stated in a study that teaching to achieve higher scores in student evaluation does not necessarily mean using the best teaching and learning methods. Suppose university officials use student evaluation scores to evaluate the effects of teaching and reward teacher who have received high scores. Teachers can be expected to look for the least expensive way to improve their grades in their classrooms. Wallace (1998) believes that a teacher can buy evaluation grades by reducing workload, reducing exam difficulty, lowering grading standards, etc ... but none of these actions are in line with the main purpose of teaching.

\section{Evaluation and its Effect on Teachers' Morale}

One of the common methods of evaluating teachers is evaluation by students. However, low grades and student criticism of the teacher cause anxiety, discouragement, and a lack of enthusiasm for teaching. 
Kerlinger (1998) argues that expressing students' opinions about the work of teacher makes college teachers feel hostile, humiliated, and distrustful, and as a result become alienated from their work. Simpson and Siguaw (2000) found that when evaluation results were lower than expected, faculty members were less committed to the job and the organization. Many studies suggest teachers with lower scores may have experienced a sharp decline in commitment to the organization. Gabris, Blau, et al report that the evaluation of teaching and complete job satisfaction is directly related to future teaching.

Some researchers believe that the decline in the quality of teachers' work leads to a decrease in the quality of subordinate institutions. In their experiences of the teacher evaluation process, teachers have referred to experiences that have been joyful or painful for them. If they received a high evaluation score, they would feel happy and satisfied with the job. On the other hand, if they are evaluated unrealistically, they have felt resentment and reduced job motivation. Raising the morale of teachers was one of the most difficult tasks of higher education in the 1990s. Therefore, it is necessary to pay attention to the mental health of teachers and in addition to stereotyped evaluation, to effectively evaluate the personality of the teacher and their opinions, and to study and identify ways to motivate and attract empathy and support of the teacher.

\section{Suggestions for Improving Teacher Performance Evaluation}

Evaluation by students has long been the first source of evaluation in higher education. Given that all universities pursue their own goals to improve student learning, professor evaluation will only be valid to the extent that it helps achieve educational goals and improve teaching practices, not when used as a means of control. As Stiggins (2005) points out, if the exam should help students succeed, then why not play the same role in teacher evaluation? According to Duro (2015), the continuous improvement of education requires new ways of thinking about evaluation. The result of student evaluation of teaching effectiveness are a useful tool in critical judgment of higher education. In a qualitative study to determine the validity of students' evaluation of teaching, it was found that this type of evaluation is effective in determining the strengths and weaknesses of teachers and helps to improve their performance.

The following tips are briefly suggested:

- For assessment to be recognized as a tool for professional learning and to allow teachers to direct and reinforce their activities, it must be considered as a process that requires a precise definition in the initial models as well as an appropriate systematization.

- Different sources of data and tools for evaluation are needed to obtain a comprehensive view of how the university is taught.

- Comprehensive assessment mechanisms not only improve individual teaching methods for teachers but are also the first steps towards reflective teaching.

- If using a questionnaire, students should only judge directly about the effectiveness of teaching: excellent, appropriate, and unacceptable.

- If students' opinions can affect a teacher's performance, they should be collected at least in two time periods: in the middle of the semester and at the end of it.

- Performance evaluation should respond to specific problems in the environment in which the teacher is located. Understanding that teaching is a complex activity must be analyzed from different perspectives.

- In addition to the suggestions of other authors, it is suggested that: by holding briefings for students, inform them of the results of the evaluation, its effects, accuracy and seriousness, and ask them to complete the evaluation form responsibly and without personal intention.

- To increase the validity of the evaluation, it is better not to use the evaluation score of students as the only criterion. And other methods such as peer review, manager, self-assessment...Be used.

- Design an accurate, sensitive and accurate measurement tool to minimize negative consequences.

- Along with announcing the evaluation results, provide guidelines on exploiting strengths and weaknesses and ways to improve teaching. 
- They were establishing a relationship between evaluation and the process of teacher education and their professional development.

- For teacher evaluation to be effective, it needs to be seen as a comprehensive and integrated approach, not as a single event in the educational organization.

\section{Conclusion}

Undoubtedly, evaluation due to its special nature in any educational system is one of the most widespread and controversial topics in the educational process, so that the reform of the system and the foundation of educational activities in universities are both issues that are completely dependent on the issue of evaluation of faculty members. Although evaluation is logical and necessary, and by doing so, one can understand the positive and negative points of programs and teaching. But it requires a proper, sensitive and accurate measurement system and tools so that both the evaluation is done correctly and the negative consequences are minimized. Doing so requires gathering the necessary information about the teacher's educational activities and selecting criteria for comparing the information obtained with those criteria and then judging to what extent teachers have achieved the predetermined goals. Since there are different models for evaluating the performance of teachers and faculty: Evaluation by officials, evaluation by colleagues, evaluation by students and sample evaluation, One cannot be satisfied with one of them and decide on the master. In evaluating teacher performance, at least four basic components should be considered: a) teacher thinking, b) teaching and learning planning, c: teaching practice in the classroom, $\mathrm{d}$ : evaluation of student results. These components can be used as a basis for analysis. Finally, using students' opinions as a source of information in evaluating the quality of education and how teachers work may be useful as feedback; But using such views alone is not enough for decision-making purposes, hiring, raising salaries, promoting and firing teachers. It is essential for each higher education center to be able to create a basic framework with specific criteria and indicators for evaluating the performance of teachers.

\section{References}

Akhlaghi, Faezeh, et al. "Evaluating the Quality of Educational Programs in Higher Education using the CIPP Model of Health Information Management." vol. 4, no. 3, 2011, pp. 621-629.

Aleamoni, Lawrence M. "Student Rating Myths Versus Research Facts from 1924 to 1998." Journal of Personnel Evaluation in Education, vol. 13, 1999, pp. 153-166.

AlterioAriola, G., and H. Pérez Loyo. "Evaluation of the Teaching Function according to the Performance of Teachers and Student Opinion." Journal of Higher Medical Education, vol. 23, no. 3, 2009, pp. 1-14.

Amaranti, Maura. "Uso de Resultados de la Evaluacióndocente Para Mejorar la Calidad de la Docencia Universitaria." Congreso Universidad, vol. 6, no. 1, 2017.

Aslam, MN. "Student Rating as an Effective Tool for Teacher Evaluation." Journal of College of Physicians Surgeons Pakistan, vol. 23, no. 1, 2013, pp. 37-41.

Baird, John S. "Perceived Learning in relation to Student Evaluation of University Instruction." Journal of Educational Psychology, vol. 79, no. 1, 1987, pp. 90-91.

Beran, Tanya N., and Jennifer L. Rokosh. "Instructors' Perspectives on the Utility of Student Ratings of Instruction." Instructional Science, vol. 37, 2009, pp. 171-184.

Betoret. Fernando, and Adela Descals Tomas. "Evaluation of the University Teaching / Learning Process for the Improvement of Quality in Higher Education." Journal of Assessment \& Evaluation in Higher Education, vol. 28, no. 2, 2003, pp. 165-178.

Blau, Gary. "Testing the Longitudinal Impact of Work Variables and Performance Appraisal Satisfaction on Subsequent Overall Job Satisfaction." Human Relations, vol. 52, 1999, pp. 1099-1113.

Braga, Michela, et al. "Evaluating Students' Evaluations of Professors." Economics of Education Review, vol. 41, 2014, pp. 71-88. 
Budig, Gene A. "Presidential Opinions on Today's Key Issues." AGB Reports, vol. 28, 1986, pp. 22-23.

Canales, A., et al. "Methodological Approaches to the Analysis and Evaluation of Teaching." The Evaluation of Teaching at the University Perspectives from Research and Professional Intervention, 2004, pp. 87-201.

Centra, John A. "Will Teachers Receive Higher Student Evaluations by Giving Higher Grades and Less Course Work?" Research in Higher Education, vol. 44, 2003, pp. 495-518.

Clayson, Dennis E., and Debra A. Haley. "Student Evaluation in Marketing: What is Actually Being Measured?" Journal of Marketing Education, vol. 12, no. 3, 1990, pp. 9-17.

Cortés, Ernesto, et al. "Prioritization of the Dimensions of Teacher Performance Evaluation by Students, in Three Areas of Knowledge." Formación Universitaria, vol. 7, no. 2, 2014.

De Costa, Meredith, et al. "A Desire for Growth: Online Full-Time Faculty's Perceptions of Evaluation Processes." Journal of Educators Online, vol. 12, no. 2, 2015.

Des Jarlais, C. D. "Determinants of Faculty Morale in an American Public Research University: Gender Differences within and between Academic Departments." Dissertation Abstracts International, 1996.

Duro, E. "Trends and Scope in the Field of Educational Evaluation in Latin America: Complementarity between External Models and Self-Evaluating Processes in Pursuit of Continuous Improvement." IV ReLac Conference, 2015.

Eiszler, Charles F. "College Student Evaluations of Teaching and Grade Inflation." Research in Higher Education, vol. 43, no. 4, 2012, pp. 483-501.

Gabris, Gerald T., and Kenneth Mitchell. "The Impact of Merit Raises Scores on Employee Attitudes: The Matthew Effect of Performance Appraisal." Public Personnel Management, vol. 17 , no. 4 , 1988, pp. 369-385.
Gall, Annette Rashid. Faculty Perceptions of the Effects of Student Evaluations of Teaching on Higher Education Instructional Practices and Instructor Morale. Marshall University, 2004.

Gaytán, S. "Evaluate Teaching: Meta-Evaluator Study of the Development of the Student Survey Process and its Reliability in the Degree in Biology at the University of Seville." Quality, Evaluation and Surveys of University Teaching, 2012.

Hallinger, Philip. "Using Faculty Evaluation to Improve Teaching Quality: A Longitudinal Case Study of Higher Education in Southeast Asia." Educational Assessment, Evaluation \& Accountability, vol. 22, 2010, pp. 253-274.

Hénard, Fabrice, and Soleine Leprince-Ringuet. The Path to Quality Teaching in Higher Education. OECD Publications, 2010.

Karimi, Fatemeh, et al. "Faculty Members' Views on the Evaluation of Professors by Students." Journal of Educational Strategies, vol. 4, no. 4, 2011, pp. 171-175.

Kerlinger, Ferd. Foundations of Behavioral Research. 1998.

Kogan, Lori R., et al. "Student Evaluations of Teaching: Perceptions of Faculty based on Gender, Position and Rank." Teaching in Higher Education, vol. 15, no. 6, 2010, pp. 623-636.

Kohli, A. K., and Bernard J. Joworski. "The Influence of Coworker Feedback on Salespeople." Journal of Marketing, vol. 58, no. 4, 1994, pp. 82-94.

Kulik. James A. "Student Ratings: Validity, Utility, and Controversy." New Directions for Institutional Research, 2001, pp. 9-25.

Loaiza Jara, O., et al. "Bayesian Networks for the Study of the Influence of Teacher Evaluation on the Academic Performance of Students from the Faculty of Engineering and Architecture of a Private Confessional University." Revista de Investigación Apuntes Universitarios, vol. 6, no. 1, 2016, pp. 61-77. 
Luna Serrano, Edna, and Vicente Arámburo Vizcarra. "Variables associated to University Instructors Effectiveness based on the Student's Evaluations." Education Policy Analysis Archives, vol. 21, no. 1, 2013.

MacMillan, M., et al. "Evaluating Teaching as the First Step to SoTL." SoTL Commons Conference, 2010.

Marsh, Herbert W. 'Students' Evaluations of University Teaching: Dimensionality, Reliability, Validity, Potential Biases, and Utility." Journal of Educational Psychology, vol. 76, no. 5, 1984, pp. 707-754.

Marsh, Herbert W. "Students' Evaluations of University Teaching: Research Findings, Methodological Issues, and Directions for Future Research." International Journal of Educational Research, vol. 11, no. 3, 1987, pp. 253-388.

Molero, D., and Juan Carrascosa. "La Evaluación de la Docencia Universitaria: Dimensiones Y Variables Más Relevantes." Revista de Investigación Educativa, vol. 23, no. 1, 2005, pp. 57-84.

Montoya, Juny, et al. "Evaluation of University Teaching in Mexico, Chile and Colombia: Analysis of experiences." Ibero-American Journal of Educational Evaluation, vol. 7, 2014, pp. 15-42.

Moore, Sarah, and Nyiel Kuol. "A Punitive Bureaucratic Tool or a Valuable Resource? Using Student Evaluations to Enhance your Teaching." Practice of University Learning and Teaching, 2005.

Murray, Harry G. "Does Evaluation of Teaching lead to Improvement of Teaching?" International Journal of Academic Development, vol. 2, no. 1, 2005, pp. 8-23.

Pascual Gómez, Isabel, and Jose Luis Gaviria Soto. "The Problem of Reliability in the Evaluation of Teaching Effectiveness in the University: A Methodological Alternative." Spanish Journal of Pedagogy, vol. 62, 2004, pp. 359-375.
Saravi, Kerman, et al. "Nursing Student and Teachers' Viewpoints toward Priorities in Teachers Evaluation." Iran Journal of Nursing, vol. 24, 2011.

Seldin, Peter. "How Colleges Evaluate Professors: 1983 v. 1993." 1993.

Simpson, Penny M., and Judy A. Siguaw. "Student Evaluations of Teaching: An Exploratory Study of the Faculty Response." Journal of Marketing Education, vol. 22, no. 3, 2000, pp. 199-213.

Spooren, Pieter, and Dimitri Mortelmans. "Teacher Professionalism and Student Evaluation of Teaching: Will Better Teachers Receive Higher Ratings and Will Better Students Give Higher Ratings?" Educational Studies, vol. 32, no. 2, 2005, pp. 201-214.

Stiggins, Rick. "From Formative Assessment to Assessment for Learning: A Path to Success in Standards-based Schools." Phi Delta Kappan, vol. 87, no. 4, 2005, pp. 324-328.

Stroebe, Wolfgang. Student Evaluations of Teaching: No Measure for the TEF, https:// www.timeshighereducation.com/comment/ student-evaluations-teaching-no-measure-tef.

Vaillant, Denise. "Some Reference Frameworks in Teacher Performance Evaluation." IberoAmerican Journal of Educational Evaluation, vol. 1, no. 2, 2008, pp. 7-22.

Wallace, J.J., and W.A. Wallace. "Why the Costs of Student Evaluations have Long since Exceeded their Value." Issues in Accounting Education, vol. 13, no. 2, 1998, pp. 443-448.

Weinberg, Bruce A., et al. "Evaluating Teaching in Higher Education." Journal of Economic Education, vol. 40, no. 3, 2009, pp. 227-261.

Wellein, Marlea G., et al. "A Peer Review Process for Classroom Teaching." American Journal of Pharmaceutical Education, vol. 73, no. 5, 2009.

Wilson, Robin. "New Research Casts Doubt on Value of Student Evaluations of Professors." Chronicle of Higher Education, 1998. 
Wolfer, Terry A., and Miriam McNown Johnson. Zabaleta, Francisco. "The Use and Misuse of Student "Re-Evaluating Student Evaluation of Evaluations of Teaching." Teaching in Higher Teaching: The Teaching Evaluation Form." Education, vol. 12, no. 1, 2007, pp. 55-76. Journal of Social Work Education, vol. 39, Zelby, L.W. "Student-faculty Evaluation." Science, no. 1, 2003, pp. 111-121. vol. 183, 1974, pp. 1267-1270.

\section{Author Details}

Mohammad Mohammadi, Lecturer, Herat University, Herat, Afghanistan, Email ID: fardin.m400@gmail.com 